\title{
Sharia Cooperatives' Productive Waqf Management Model Through Financial Technology Services in Bandung City Area to Promote The People's Economy
}

\author{
Nurjamil $^{1 *}$, Siti Nurhayati ${ }^{2}$ \\ ${ }^{1,2}$ Lecturer at IKOPIN Jatinangor, Sumedang, West Java, Indonesia \\ ${ }^{*}$ Corresponding author: \\ Email: nurjamil@ikopin.ac.id
}

\begin{abstract}
Waqf continues to develop as a pillar of people's economic power, from the conventional land waqf concept of social and educational facilities to the modern enough stage, now known as cash waqf money, cash waqf linked sukuk (CWLS) and fintech linked to the waqf fundraising process. The aim of this study is to provide an understanding of the legal status of waqf producers, through the use of fintech applications in the context of Law No. 41 of 2004 on Waqf and Law No. 11 of 2008 on Electronic Information and Transactions, and through a processing methodology to find an economic empowerment model for people with productive waqf assets. The study uses a methodology which refers to qualitative legal research. Research findings concluded that Fintech apps are not properly regulated by Waqf of the ITE Law, but are still permitted to be used in the management of cash waqf as long as they are not in breach of the law in force. In the management of waqf. Nazhir shall be liable and may be prosecuted in the event of a loss of waqf properties due to its negligence. Sharia Cooperatives registered as cash waqf nazhir and in cooperation with Bandung City Fintech companies are owned by BMT ITQAN only where they are financed by itqanmobile and involve the Fintceh platform kitawakaf.com with the help of the House Financing Assembly empowerment program for BMT member SMEs with waqf funds and the waqf management models..
\end{abstract}

Keywords: Productive Waqf, Sharia Cooperative, Financial Technology, Economic Empowerment

\section{INTRODUCTION}

A prosperous society of justice is the main purpose of the foundation of the Indonesian State. Development is an effort and a real step by the government to achieve the ideals of the nation, namely by maximizing natural resources and tax revenues. As the country with the largest Muslim population in the world, Indonesia also has the economic potential of large social funds, one of which is waqf. In Islam, two main systems of distribution of wealth are known. First, commercial disribusi and follow the market mechanism through economic activities and second distribution, focusing on the social justice aspects of the community through the concepts of zakat, infaq, shadaqah, inheritance and waqf. [1]. Waqf is a form of philanthropy known in the Islamic civilisation since Prophet Muhammad's time, and has contributed significantly until the time of the Islamic Caliphate. [2]. The political waqf of Islamic Law in Indonesia has therefore taken it into account in a positive law, as laid down in Law No 41 of 2004 on the Waqf (hereinafter referred to as the Waqf Law) [3].

The potential of land waqf in Indonesia is currently over Rp 370 billion and even reached Rp value, according to data from the Indonesian Wakaf Agency (BWI). 2000 trillion while Rp 180 trillion is the cash endowment. According to the Republic of Indonesia Minister for Religious Affairs, released by the Indonesian Waqf Council [4], In Indonesia, the waqf area is 268653.67 hectares spread over 366,595 locations across Indonesia, with productively managed areas which can certainly promote economic 
growth and acceleration in Indonesia. The potential of the waqf as one of the sources of religious social funds is so important that the government reached a major consensus in the Medium Development Plan (RPJMN) 2020-2024 on the development of sharia economies, including to promote better and more transparent management of religious social funds, accountability, ownership and professionalism and optimize its use for religious social funds. [5].

Waqf is one source of Sharia economy philanthropy funds that can improve people's general welfare and enhance the economy. The role of waqf should be strengthened not just to provide different ways of worship and of social affairs but to provide Sharia banks with the role and function of social funds not being explored optimally (tabarru). This is in compliance with Article 4(3) of Law No. 212008 on Sharía Banking (UUPS) which states that: Sharia and US banks may collect waqf-based social funds in accordance with the wishes of waqf donors and distribute them to waqf managers (nazhir) (wakif). In addition, Article 28 Waqf law says that, via Sharia financial institutions (LKS) including Sharia Cooperatives, wakif can produce moving objects in the form of money.

In practice, Mandiri Cash Platforms (ATMs), eBanks, and electronic systems perwakafan are commonly used in financial-technology applications to enable the reception of public waqf funds by the Minister of Religious Affairs using information technology or electronically. Sharia Financial Institutions (LKS) (hereinafter written fintech). This is because information developed in electronically (electronically based) is increasingly recognized for its efficiency in the manufacturing, processing, and storage of electronics. The public can handle and deposit waqf funds face-to-face to make it easy for the public to accept accountabilities. The national Amil zakat agency is a philanthropic fundraising agency which implements Fintech in transactions (hereinafter written BAZNAS). However, new legal issues remain for waqf transactions through Fintech applications. Under the terms of Article 17 of the Waqf Law and Article 218 of the Compilation of Islamic Law (KHI) the Waqf Pledge shall be fulfilled and included in the contract with wakif, nazhir and witnesses. This becomes necessary to achieve legal certainty for participants involved in the waqf pledge.

Based on the above explanation, waqf as a pillar of Islamic social finances (ISF) has undergone a major transformation, starting with the traditional religion and ending up with the modern economic and social culture. From waqf assets to waqf money, then waqf money and the waqf era in combination with the concept of financing. In the latter concept, WAQF is partnered to the management roles of the WAQF with companies, such as the concept of sukuk related waqf and wakaf development, in conjunction with Islamic financial institutions, through the concept of financial technology (fintech) in the aim of contributing more to the achievement of sustainable development objectives. waqf

Fintech as a breakthrough in the financial industry, which is now turned into a popular, demandand naturally potential-oriented industry, is widely used to deliver services to the community, particularly for those who want facilities with functions that are simple, fast, and accessible to everyone who cannot access banking (non-bankable). Tech-based finance services, then used in the field of social finance, in particular money waqf management, of course, have their own characteristics and treatment and difficulties. Further research is needed to develop the management and development model for the use of fintech in waqf development.

\section{METHODS}

This is a qualitative descriptive investigation which describes qualitatively the actual situation in research objects. The method of approach used in this research is the method of legal guidelines. The approach is examined only as secondary data and literature studies from the point of view of written laws and rules. In this instance, KSPPS BMT ITQAN is the collection and collection of primary data obtained

$\underline{\text { http://ijstm.inarah.co.id }}$ 
directly from the cash waqf manager in the library and area research of IKOPIN, the research stage undertaken by the author is that of collecting secondary data sources in the library IKOPIN (The one who did waqf). The collected data is then analyzed and supplied.

\section{RESULT AND DISCUSSION}

Productive Waqf status and position Through Fintech Application In accordance with Law No. 41 of 2004 and Law No. 11 of 2008 on information and electronic transactions

Productive waqf by fintech is a new thing not previously known. This is part of the waqf development process itself, to make it possible to maximize the potential of such a large waqf. Under current rules, all types of waqf development are designed to enhance the productivity value of waqf, and meet the sharia principles criteria, which naturally apply in compliance with the Waqf law. Article 43(2) of the Waqf Law clearly states: The waqf property is managed and developed productively as referred to in paragraph (1). The productivity of management under consideration must be based on the principles of Sharia law as laid down in Article 43(1) of Waqf Act that: the waqf property, managed and developed by nazhir in accordance with the principles of Sharia law as referred to in Article 42 and also stated in Article 45, paragraph (2), of the PP, of 2006, of Law 41 of 2004 on the implementation of Waqf.

In the explanation of Article 43 (2) of the Waqf Act, the waqf development model is described as follows: managements and develops waqf property productively, for example through the collection, investment, investment, production, partnership, trade, agribusiness, mining, industry, technology development, construction and development of waqf properties

In particular with respect to Fintech, no one Article explicitly regulating the concept of productive waqf via Fintech was found in the Waqf Law. Waqf law provides only for norms regarding objects which may diwakafkan, whether moving or immobile, as a collateral, confiscated, sold, allowed, and inherited for the prohibition of waqf objects. In practice, more is done as waqf cash or cash waqf as an accelerator media for productive waqf development. The waqf-money provisions of Article 28 to Article 31 of the Waqf Law with the following provisions in particular:

\section{Article 28}

Wakif can make moving objects in the form of money through Islamic financial institutions appointed by the Minister.

\section{Article 29}

(1) Waqf of moving objects in the form of money as referred to in Article 28 shall be implemented by Wakif with a statement of Wakif's will made in writing.

(2) The waqf of moving objects in the form of money as referred to in paragraph (1) shall be issued in the form of a money waqf certificate.

(3) The certificate of waqf money as intended in paragraph (2) is issued and submitted by sharia financial institutions to Wakif and Nazhir as proof of submission of waqf property.

\section{Article 30}

Sharia financial institutions on behalf of Nazhir register waqf property in the form of money to the Minister no later than 7 (seven) working days from the issuance of the Money Waqf Certificate.

\section{Article 31}

Further provisions on the waqf of moving objects in the form of money as referred to in Article 28, Article 29, and Article 30 shall be stipulated in a Government Regulation.

In computer, computer network and/or other electronic media, Electronic Trade Acts are defined as legal acts carried out by means of ITE Law. ITE Law provides opportunities for state organizers, 
individuals, businesses and/or the public to use information technology properly, and the use of information technology must be made to achieve maximum benefits for the Community.

Fintech is a new model of financial services that focuses on companies innovating with a touch of modern technology in the field of financial services. A more practical, secure, modern financial transaction process should be facilitated by the concept of fintech as an application. Fintech is a way to make financial transactions easier. The people are no longer limited by distance and time with Fintech applications. Fintech applications provide facilities which all, including those not eligible for banking facilities and services, can access or those not eligible for transactions with financial institutions such as banks.

This allows it to be used legally by any medium, which can, in principle, be applied to increase waqf management's productivity value and according to Sharia principles. With regard to fintech, the use of fintech in management of productive Waqf, including the money waqf, cannot in this case contravene legal norms such as the Waqf law, ITE law and the MUI Fatwa on Waqf Money and may be classified as media or as means which enable the community to hold position.

\section{Managing Productive Waqf Responsibility Nadzir based on Fintech in Sharia Cooperatives.}

In addition to money like land and buildings, productive waqf management (cash waqf) differs from the management of waqf. Waqf money can only be used for nazhir which complies with the nazhir requirements as set out in BWI Regulation No 2 Year 2010, which applies to Nazhir Wakaf Uang, as set forth in Waqf and Pemerinth Regulation No. 42 of 2006 on implementation of Waqf Law. The Nazhir Wakaf money recorded with BWI reached 224 institutions in October 2019, based on BWI data (BWI, 2019a) The BWI, the PBNU, the Daaruttauhid and the Sharia Co-operatives are both the KSU and the KSPPS. Practically nazhir money waqf managers cannot be separated from issues such as the temporary money waqf time period, the wakif who are not meeting wakif (not lawfully law-enabling) legal requirements and the Nazhir responsibility problem in managing waqf funds themselves. In this subsection, researchers will discuss the responsibilities of nazhir in the administration of fintech money. Regarded the responsibilities of nazhir, it is expressly stated in Article 42 of the Waqf Act where nazhir is responsible for waqf management and where nazhir receives a maximum of $10 \%$ of the net income from waqf property management and $90 \%$ of the income is distributed to beneficiaries (mauquf alaih) (Refer to Artcile 12 Waqf Law).

The law of the Treaty which gave birth to the alliance, however, underpins the right to manage the waqf of Nazhir's money. In this case, the waqf promises made by wakif becomes legal standing for Nazhir, in which case the administration of the waqf money by portopolio wakaf management, owned by nazhir, is subject to law against waqf (mauquf bih). Based on the principle of contractual freedom [7], Then, as long as Wakif and the Nazhir meet the requirement of the validity, both subjective and agreed terms, as well as objective terms which include certain things, and halal kausa/something that does not breach religion, law, decency and property standards, all kinds of agreements can be made by them.

Waqf property is generally a property donated by wakif to be run by nazhir to provide the community with the best possible benefits, in line with wakif wishes and laws. This is consistent with the views conveyed by H.M. Salim Umar as the Islamic law experts. During the interview with the president of the West Java Committee on Mui Fatwa on 2 July 2014, at 09.45 wib, the information was obtained on the occasion of a researcher interview, stated in the Office of the presidency of the Western Java Committee on MUI Fatwa:

"Indeed, the benchmark for the concept of waqf, usually called "holding" is not that of the waqf property itself but the continuity of the value for the community of the benefits of waqf results. In the next development, the results of the fatwa Commission deliberations by the third Indonesian Ulme Council, 
held in Padang Panjang in 2009, stated that both waqf, in the form of money, can be exchanged for money on two terms, namely that there are greater benefits and the existence of harsh circumstances."

What remains in the waqf property is therefore not limited only to the existence of waqf objects themselves, but also to the value of waqf assets managed by nazhir which is even more important. Here, nazhir is very interested to preserve the advantage of the waqf property itself. Nazhir has the flexibility in the management of waqf in allocating waqf funds in various models to develop waqf management of property which do not contravene the law and comply with the Sharia criteria.

Article 43(1) of the Waqf law explicitly states that "The management and development of waqf property by nazhir as referred to in Article 42 shall be implemented in accordance with sharia principles" according to the law of the Waqf. Moreover, Article 45(2) PP No. 42 of 2006 on the application of Law no. 41 of 2004 on waqf states that Nazhir may cooperate with other parties, in line with the sharia principles, in the administration and the development of waqf property referred to in paragraph (1), for the promotion of general welfare."

In addition, in Article 43(2) of the Waqf Law which states: The models for developing productive Waqf property management are described in the explanation:

'Waqf property is managed and developed, inter alia, by the production, investment, manufacture, partnerships, trade, agri-business, mining, industry, technology development, building construction, apartments, flats, supermarkets, shops, offices, educational establishments or healthcare facilities not in breach of Sharia rules.'

As to the management and operations of Nazhir money waqf, there are several models of development: firstly the buying of shares in the LQ 45 category by means of a capital market; secondly, the buying of sukuk for the government's guarantee of strategic projects; thirdly, the purchasing of capital investments as shares of the company; fourthly, t. the purchase of sukuk for strategic projects; third.

The first scheme is almost non-existent, as investments in government guarantees could be said to be the risk borne by the Nazhir. In the second system, Nazhir actually has very large risks, yet Sharia Guarantor institutions that minimize the risk of Nazhir have been determined by the Indonesian Capital Market Act. Sharia guarantor institutions shall be involved if necessary, as provided for in Article 43 (3) of the Waqf Law, where: the guarantor shall be used by Sharia Guarantor Institutions in the case of management and development of waqf properties as set up in paragraph (1).

In the third system, Nazhir has placed waqf funds in the business sector as a capital investment both for Nazhir-run companies and other Nazhir business partners. In this case the management of nazhir is in great risk of losing or failing the company if the shares can be guaranteed for loss or objects of confiscation, as well as the profits which might add value to the benefits of waqf, while Article 40 of the law of Waqf states that property of waqf which has been deposited is prohibited: 1). made a guarantee; 2. Seized; 3. Seizures. 4.sold; 5. Grants; Layed; 6. Layed. Exchanged or exchanged; or 7. Transferred as other transfers of rights.

The Fourth Scheme, in which nazhir allocates waqf funds in real sector financing, poses a risk of non-reforming (NPF) funding which may cause waqf funds to be reduced or even lost.

If a problem exists as outlined above, several approaches can be taken in legal terms, namely:

1. Where, due to a mistake on the part of nazhir, the problem is either deliberate or negligent and not prudent, nazhir shall be held liable for the error, according to its responsibility (based on fault). It is laid down, in particular, in Articles 1365, 1366, and 1367 in the Civil Code (hereinafter KuHPerdata). This principle states that if there is an element of wrongdoing a new person can be held legally responsible. Unlawful act (PMH), known also as onrechtmatige daad (international daad), Article 1355 of the Civil Code [8] requires the fulfillment of four main elements, namely:

$\underline{\text { http://ijstm.inarah.co.id }}$ 
a. Unlawful acts; b. There is an element of error; c. Losses suffered; d. There is a causality relationship between deeds and losses.

Thus, if some provisions relating to the principle of liability based on errors can be proven, then nazhir is required to indemnification and refund the waqf.

2. If the problem as mentioned does not arise from the fault of Nazhir, nazhir is not held liable, morally and legally in this case. This means that waqf property shall be indemnified in cooperation with nazhir by other parties in accordance with the default or unlawful acts specified in KHPerdata.

3. Registration No 3.3.00076 is registered as the Nazhir wakaf uang on 7 October 2014, which is then updated with Registration No 2.3.00076, valid from 14 January 2020 to 14 January 2025 with an address of the Sharia Coopérative in Bandung, with the number KSPPS BMT ITQAN, as the only Sharia cooperative that holds a license or has registered a money waqf nazhir in Bandung. Tower No. 160, RT. 02 RW. The Cooperation Agreement between Asset Managers Wakaf ITQAN (PAWI) and KSPPS BMT ITQAN in this case acts as investment management, 03 Pasir Layung Subdistrict Cibeunying Cidul Bandung, Tel: 022-7209248, legal protection of waqf assets in this instance waqf money. The agreement stipulates that waqf assets, in the form of money invested in SIJAKA products, are safeguarded by term deposits, such as deposits deposited for KSPPS BMT ITQAN Member Finance programmes. Sharia co-operatives hereby express a commitment to manage the waqf funds with trust, professionals and to return waqf funds in their totality, where PAWI is withdrawn for a single moment. In case of problems, like Non-performing financing or customer defaults, the waqf funds is considered part of a risk born by KSPPS BMT ITQAN.

The Sharia Cooperatives Productive Waqf Management Model (Fintech) application to the Bandung city region in efforts to empower the people's economy.

This subchapter provides researchers with a discussion of the findings of research carried out in the Bandung Sharia Co-operative on the use of fintech applications for the management of funds. As described above, nazhir, who have the right to manage waqf money, has special conditions for waqf money and must be registered as a waqf Nazhir with the Indonesian Waqf Board. Following research in Bandung, only one Nazhir wakaf money is included in the BWI-registered cooperative.

1. The use of fintech in KSPPS BMT ITQAN money waqf management began in 2018. KSPPS BMT ITQAN was at that time cooperating with a company called the Sharia Fintech PT. Ammana Fintech Syariah is a Sharia finech company based in Saharjo Square Building Jl (https://ammana.id). Dr Saharjo No. 49. RT.3/RW.8. Jakarta Capital City 12850. Indonesia. Saharjo No. 49. RT.3, RW.8. The company is a Member of the Indonesian Joint Funding Fintech Association (AFPI) registered with Registry Number 00416/DJAI. PSE? PSE? PSE? 10/2017, licensed and overseen by ojk to be a partner in the fundraising process or more commonly called the waqf fund-raising process with a project base in cooperation with Panin Bank Syariah, one of the Wakaf Money Management (LKS PWU) shark financing agencies designated by the Government. The company has been appoined to participate in the fund-raising process. Due to the lack of a program or project on the market at that time KSPPS BMT ITQAN, then cooperation with PT. AMMANA Fintech Syariah has been discontinued, and the LKS PWU's waqf funds were just Rp. 6000.000 (of which until now the funds have not been taken by KSPPS BMT ITQAN as nazhir).

2. In addition, in 2019 the BMT ITQAN Sharia Cooperative cooperates on a sharia fintech enterprise, namely www:kitawakaf.com, the Sharia Fintech company formed by a PT company. Kita Wakaf Indonesia is willing, via asset manager Wakaf ITQAN (waqf management agency under the auspices

$\underline{\text { http://ijstm.inarah.co.id }}$ 
of the ITQAN Foundation), to become a partner wakaf in a program pioneered by KSPPS BMT ITQAN under the name of an Assembly Financing House (RPM), which up to now is still being

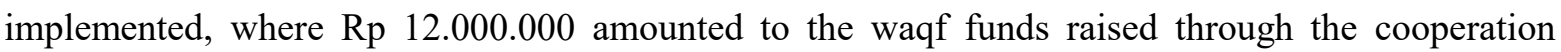
programme. Twelve thousand thousand.

3. Itqan Mobile is a Koperasi Syariah BMT ITQAN application that can also be classified as an application of financial technology that can be used for the public, in particular the members of the public, in order to carry out financial transactions without the need to enter a store or an OFFICE of KSPPS BMT ITQAN. As regards waqf, specifically the members of KSPPS BMT ITQAN who are hereby referred to as wakif may make wakaf money transactions or waqf money contracts by Itqan Mobile which then is collected by the Itqan Wakaf Asset Manager (PAWI) and managed productively in the KSPPS BMT ITQAN SIJAKA Investment Programme. A certificate of waqf money is then issued for 1 million rupiah, so it's worth more than 1 million rupiah.

KSPPS BMT ITQAN Cash Waqf Management Model to enhance Bandung City's people's economy.

The waqf concept has undergone major developments as described above. Today it is referred to as waqf money, which then differentiates in practice between waqf money and waqf by money. Based on the basic information gained by a thorough interview with a research manager from the KSPPS BMT ITQAN waqf, Edwin Gafitra Setiawan, as the Asset Manager, Wakaf ITQAN (PAWI), and Head of the Baitul Maal ITQAN Section, KSPPS BMT ITQAN has been obtained as one of the Sharia Cooperatives listed as Nazhir wakaf funds. The amount managed by Waqf was IDR 898,368,524, whereas the amount collected by waqf was totaled at IDR 75,430,222. Waqf funds managed and then invested produce returns or profits, where the income fund for mauquf alaih or the recipient that will soon be disbursed is currently worth IDR 32.684.192.

The waqf management model in KSPPS BMT ITQAN can be described in the following flowchart:

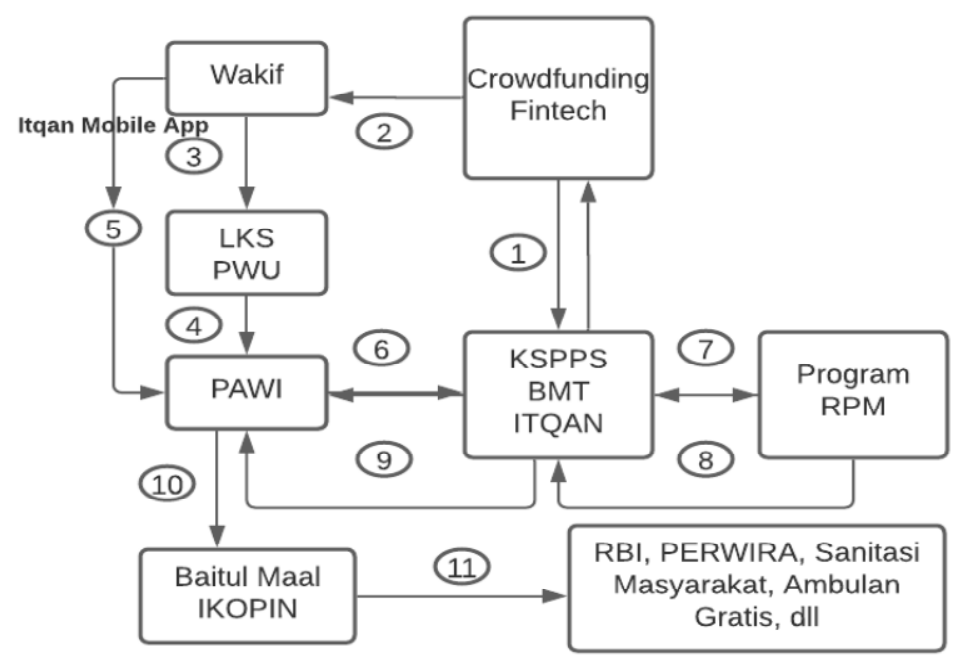

Fig I: Cash Waqf Management Model Through Fintech Application at KSPPS BMT ITQAN Bandung (ilustrated by researchers)

The following is the description of the money waqf administration model in the KSPPS BMT Itqan Bandung fintech application.:

1. KSPPS BMT ITQAN works together on the basis of the RPM project (Majelis Financing House "Rumah Pembiayaan Majelis") that is associated with financial institutions of the Bank as the 
Sharia Financial institutions Recipients of Wakaf Money nomination by the BWI, to secure the waqf funds from the local community through its financial technology facility.

2. Fintech companies attract community waqf funds through crwdfunding or fintech applications.

3. Wakif who received data on Waqf from Fintech companies' crowdfunding services handed over waqf assets as money with a waqf money deal to the PWU LKS

4. Then PAWI can take and administer funds raised in the PWU LKS.

5. Wakif can give the waqf money to PAWI directly via the ITqan Mobile Application Fintech application.

6. Through the SIJAKA products time deposit program, Waqf assets accumulated within PAWI are then invested in KSPPS BMT ITQAN as investment manager. KSPPS BMT ITQAN has made a statement. Provide PAWI with a profit share of $12 \%$ per year, b. Each year. Provide an incentive of $6 \%$, with each waqf funds being received from the KSPPS BMT ITQAN promotional fund, $\mathrm{c}$. The guarantee will be returned 100 percent of the invested waqf funds at the promised date agreed.

7. KSPPS BMT ITQAN distributes waqf money to the members, in accordance with the proposal with a mudharabah agreement, through a Rumah Pembiayaan Majelais (RPM) financing programme. RPM members shall receive funding programs which commit themselves to account for up to $0,5 \%$ of the value of funding received. RPM is extended to cluster members where one cluster is 15 to 30 MSME with the following methodologies: regional survey, general meeting, targeting, feasibility test and PPOI, obligatory group exercises, authentication group examination, center training. RPM is organized to cluster members with cluster pattern.

8. Members who are RPM fund recipients will provide the KSPPS BMT ITQAN for Hasil with a scheme of 60:40.

9. As previously stated in paragraph 3 , the fund for the proceeds of the funding program is distributed to PAWI.

10. Baitul Maal Itqan is then paid the income share PAWI obtains.

11. Baitul Maal Itqan then spent funding for the donation in the mauquf'alaih program, after deducing operating costs: Wira Usaha Training (PERWIRA), Community Healthy Latrines Development, Bina Itqan House (RBI), and ITQAN's Free Ambulance.

\section{CONCLUSION}

The concept of waqf money through fintech is not explicitly regulated by the Waqf and ITE Law. Waqf law provides for only standards for objects that may be taken into consideration, of which money (for moving objects) is a requirement that it be managed productively using the Sharia rules, in order that, in principle, fintech can be used in the management of cash waqf, whether as an enterprise which facilitates the creation of funds with crowdfinance or as a payment application,

If problems arise from nazhir errors either intentionally or negligently in the management of cash waqf such as problems with the financing of NPF or because of the prudence principle, then the responsibility based on mistakes may be held accountable by the nazhir. It is laid down, in particular, in Articles 1365, 1366, and 1367 in the Civil Code (hereinafter KuHPerdata). This principle states that if an element of wrongdoing exists, a person may be held legally responsible. Where certain provisions concerning the mistaken principles of liability can be demonstrated, nazhir must be compensated and the waqf refunded. On the contrary, if the problem as mentioned does not arise because of the fault of Nazhir, then Nazhir is not held morally or legally accountable. In cooperation with nazhir, compensation for waqf property is charged to other parties in the provision of defaults or in violation of the laws laid down in the Civil Code. 
The model of the management of waqf money through a fintech application for the shari cooperative, the only sharia cooperative that in Bandung City has the license to raise funds by means of the fintech application KSPPS BMT ITQAN in the form of the ITQAN MOBILE waqf application, cooperation with kitawakaf.com and the cash waqf program from the finance members that are invested via time deposits (SIJAKA), where the funding has to be funded in the "Rumah Pembiayaan Majelis" program (RPM) which is channeled towards community empowerment in the form of healthy community development latrines, Rumah Bina ITQAN (Santri Penghapal al Qu'ran scholarship), Free Ambulance, Business Training, etc.

\section{ACKNOWLEDGMENTS}

The authors are immensely thankful for warm encouragement, motivation, in-depth suggestions and kind advice of the IKOPIN Institutions for Research and Communal services and the full support of the Ministry of Research and Technology of Republic of Indonesia which this research was funded.

\section{REFERENCES}

[1] E. Amalia, Keadilan Ditributif dalam Ekonomi Islam, Penguatan LKM dan UKM di Indonesia,. Jakarta: Rajagrapindo Perssada, 2009.

[2] BWI, "Sejarah Wakaf," 2019. https://bwi.or.id/index.php/in/publikasi/artikel/1692-sejarah-wakaf-2habis.html .

[3] I. T. Saptono, "Pengembangan Instrumen Wakaf Berbasis Investasi Sosial, Studi Wakaf Linkeded Sukuk," Al-Awqaf, J. Wakaf dan Ekon. Islam, vol. 11, no. 2, p. 120, 2018.

[4] BWI, "Data Base dan Potensi Wakaf Indonesia," 2018. http://www.bwi.or.id/index.php/ar/component/content/article/80-database-dan-potensi-wakaf.html.

[5] Menteri Perencanaan Pembangunan Nasional/Kepala Badan Perencanaan Pembagunan Nasional, "Indonesia Menuju Pusat Ekonomi dan Keuangan Syariah Dunia, Materi High Level Discussion pada Muktamar IV Ikatan Ahli Ekonomi Islam(IAEI)," Jakarta, 2019.

[6] BWI, “Daftar Nazhir Wakaf Uang," 2019. https://www.bwi.go.id/3912/2019/10/31/daftar-nazhir-wakafuang-update-oktober-2019/.

[7] Dedi Harianto, “Asas Kebebasan Berkontrak: Problematika Penerapannya Dalam Kontrak Baku Antara Konsumen Dengan Pelaku Usaha,” J. Huk. Samudra Keadilan, vol. 11, no. 2, 2016.

[8] G. A. Kamagi, "Perbuatan Melawan Hukum (Onrechtmatige Daad) Menurut Pasal 1365 Kitab UndangUndang Hukum Perdata Dan Perkembangannya," Lex Priv., vol. 5, no. 6, 2018. 